\title{
SLOW DEEP BREATHING EXERCISE ON PATIENTS' BLOOD PRESSURE WITH HYPERTENSION IN WORKING AREA OF KERTOSARI HEALTH CENTER BANYUWANGI 2020
}

\author{
by \\ Rima Ambarwati ${ }^{1}$, Masroni' ${ }^{2}$, Anita Dwi Ariyani ${ }^{3}$ \\ 1,2,3 Banyuwangi Institute of Health Sciences Indonesia \\ Email: masroni86@gmail.com
}

\begin{tabular}{l}
\hline \hline Article Info \\
\hline Article history: \\
Received \\
Revised \\
Accepted
\end{tabular}

Keywords:

Slow Deep Breathing Exercise

Blood Pressure

Hypertension

\begin{abstract}
PT)
Slow deep breathing exercise is a non-pharmacological therapy in hypertension patients without comorbidities that can reduce blood pressure. This study aimed to investigate the effect of slow deep breathing exercise on patients' blood pressure with hypertension in working area of Kertosari Health Center Banyuwangi. This study used experimental design with One-Group Pre-test - Post-test. The sample consisted of 11 respondents who fit the inclusion criteria recruited from an observation sheet of blood pressure measurement using a digital sphygmomanometer, then processed by conducting scoring, tabulating and statistical analysis using Paired T-Test from SPSS 25 for windows. The average respondent's SBP (Systolic Blood Pressure) before SDB (slow deep breathing) was $162.82 \mathrm{mmHg}$ and after SDB was $133.27 \mathrm{mmHg}$. The average DBP before SDB was $87.91 \mathrm{mmHg}$ and after SDB was $80.09 \mathrm{mmHg}$. Further analysis used Paired T-Test found $\rho$ value $=0.000, \alpha=0.05$ or $\rho$ value $<0.05$. It can be concluded that there was a significant Effect of Slow Deep Breathing Exercise on Patients' Blood Pressure with Hypertension in Working Area of Kertosari Health Center Banyuwangi 2020.
\end{abstract}

This is an open access article under the CC BY-SA license.

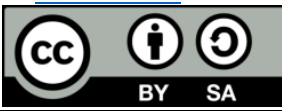

\section{Corresponding Author: \\ Masroni, \\ Department of Nursing, \\ Institute of Health Sciences (STIKES) Banyuwangi, \\ Email: masroni86@gmail.com}

\section{INTRODUCTION (10 PT)}

Hypertension is one of the most pressing public health challenges and it is recognized as the biggest contributor to the global burden of disease [1]. Hypertension is often called as the silent killer because it is a deadly disease and often does not cause complaints [2]. Even hypertension can lead to the other chronic and deadly disease and it can increase the risk of heart attack, stroke and kidney failure [3]. Hypertension is defined as systolic Blood Pressure (SBP) values more than $140 \mathrm{mmHg}$ and diastolic Blood Pressure (DBP) values more than $90 \mathrm{mmHg}$ [4]. Hypertension is also a degenerative disease, which mean the blood pressure will increase by the adding of the age [3].

Globally, World Health Organization (WHO) said that there were around 972 million people or $26.4 \%$ of people who suffer from hypertension in 2013, from the total number of 333 million people are in developed countries and rest of them, 639 are in developing countries, including Indonesia [5]. Meanwhile, in 2014 the prevalence of hypertension decreased became $22 \%$ [6]. WHO (2015) said that there were 1.13 billion people in the world suffer from hypertension. The number decreased in 2016 as many as 185,857 people suffering from hypertension [8]. Then the number increased in 2018 as many as 74.5 million people suffering from hypertension [9]. Hypertension is one of the causes of death in the world with 9.4 million of the 17.5 million people die every year [10]. Ministry of Health (2016) stated that there were 63,309,620 people who suffer from hypertension. Meanwhile the Basic Health Research (Riskesdas) 2018 showed that in Indonesia the prevalence of population with high blood pressure is $34.11 \%$ or around 87 million people of the total population. The prevalence of high blood pressure in women is higher at $36.85 \%$ or around 94 million people than men with a prevalence of $31.34 \%$ or around 80 million people [12]. The number of people with hypertension continues to increase every year. It is estimated that each year there are 10.44 million people die from hypertension and its complication. WHO estimated that the number of people with hypertension will increase to 1.6 billion by 2025 [13].

Health profile of East Java in 2017 explained that one of the provinces in Indonesia that still has problems with high rates of hypertension is East Java with the percentage of hypertension is $20.43 \%$ or around $1,828,669$ 
populations, with the proportion of men $20.83 \%$ or 825,412 populations and women $20.11 \%$ or $1,003,257$ populations [12]. Meanwhile, in Banyuwangi percentage of hypertension is 30\% of the total population [14]. According to data from the Banyuwangi District Health Office in 2018, Kertosari Health Center was second rank after Sobo Health Center which had the highest hypertension rates, as many as 2,879 patients [15]. Meanwhile, according to the results of a preliminary study conducted on November 4th 2019, there were 818 people who had hypertension in the working area of Kertosari Health Center.

WHO showed that hypertension can be caused by Behavior and lifestyle includes eating too much salt (sodium), not eating enough potassium (from fruits and vegetables), being overweight, not getting enough exercise, as well as drinking too much alcohol and smoking and also hereditary [16]. Uncontrolled hypertension will cause stroke, myocardial infarction, kidney failure, encephalopathy, and seizures. A serious complication of hypertension is death due to obstruction and rupture of brain blood vessels [17]. Rupture of brain blood vessels causes bleeding in the brain. This bleeding will be fatal because it can cause brain swelling and death of brain cells. Brain cells that die for a long time can lead to a coma and even death [18].

Hypertension can be managed by one of the exercises and relaxation namely slow deep breathing (SDB) exercise. SDB is a relaxation that is realized to regulate breathing deeply and slowly. SDB exercise can increase the sensitivity of baroreceptors and reduce the activity of the sympathetic nervous system and increase the activity of the parasympathetic nervous system in patients with hypertension [17]. When the parasympathetic nerves increase, the body's activity will decrease and relaxation occurs. If this condition occurs regularly it will activate cardiovascular control Center (CCC) which will cause a decrease in heart rate so that can reduce the BP [19].

Hypertension management can be done in 2 ways those are pharmacologically and non-pharmacologically. Meanwhile, Williams et al. (2018) explained that there are two well established strategies to lower BP: lifestyle interventions and drug treatment. Pharmacological therapy depends on antihypertensive drugs. Consumption of drugs in the long term can affect the body's organs, especially aggravating the kidneys' work. If this happens, the morbidity and mortality rate due to kidney failure will increase [20]. While non-pharmacological therapy involved five lifestyle modifications are recommended for reducing blood pressure: reducing sodium intake, increasing exercise, limiting alcohol consumption, dietary changes, losing weight, smoking cessation, dietary supplements and meditation [2].

Hypertension can also be managed by doing simple exercises such as slow deep breathing. Slow Deep Breathing is a simple relaxation technique where the lungs are allowed to breathe as much oxygen as possible [21]. Slow deep breathing is an act done consciously to regulate breathing deeply and slowly [22]. Doing SDB are also needed to reduce blood pressure [17]. SDB exercise can be done whenever, wherever by anyone very easily, and it is safe for the user [23].

\section{RESEARCH METHOD (10 PT)}

This study was conducted in an experimental design using quantitative approach with One-Group Pre-test Post-test design. In this study, before being given intervention, variable was observed or called pre-test, then carried out intervention. After giving intervention, the variable was observed further or called the post-test.

\begin{tabular}{llll} 
Participant & $\mathrm{X}$ & $\mathrm{O} 2$ \\
\hline
\end{tabular}

Note:

$\mathrm{X} \quad$ : Intervention for Participant

O1 : Observation of Participants before Intervention

$\mathrm{O} 2$ : Observation of Participants after Intervention

The population in this study were all of hypertension patients in working area of Kertosari Health Center in 2019 with the number of 818 patients. The sampling technique used in this study was accidental sampling. The samples in this study were some of hypertension patients who seek treatment at Kertosari Health Center in 2020 with the number of 11 patients.

This research was conducted in working area of Kertosari Health Center on March, 11th to March, 25th 2020. The independent variable in this research was Slow Deep Breathing Exercise and the dependent variable in this research was Patients' Blood Pressure with Hypertension. The instrument used in this research was observation sheet and a blood pressure measurement tool, this is digital sphygmomanometer.

Before the researcher conducted the research, the researcher approached administratively to the education or institution first by submitting an initial data collection permit to conducted research from STIKes Banyuwangi through the Institute for Development and Community Service submitted to the Head of the Kertosari Health Center. After obtaining approval, the researcher distributed informed consent sheets to participants. Researcher chose additional data collector of 1 people to assist in measuring BP and providing SDB exercise. The researcher 
conducted training for additional data collector about research procedures to equalize perceptions in BP measurement and the provision of SDB exercise. Researcher explained the purpose of the study to participants. After getting an explanation, the participant was asked to fill out an informed consent. Participant was suggested to relax from previous activities while 15 minutes before taking BP measurement. Researcher and data collector took BP measurements on participants 1 minute before giving SDB exercise. Researcher and data collector gave SDB exercise by breathing in through the nose and inhale for 3 seconds, feel the abdomen expand. Then, Hold the breath for 3 seconds. The last step was exhale slowly for 6 seconds. Repeat all steps for 15 minutes Then, Researcher and data collector took BP measurements 1 minute after giving SDB exercise. Slow Deep Breathing exercises were done with a frequency of twice a day for two weeks.

After the data was collected then researcher conducted editing, coding, scoring, and tabulating process. Before determining the data analysis, the researcher conducted a normality test. In this study, the normality test used was the Shapiro-Wilk test because the sample was less than 50 with the $\rho$ value $>0.05$. Based on the results of the normality test, researcher decided to analyze the data using the Paired T-Test with the $\rho$ value $<0.05$.

\section{RESULTS AND ANALYSIS (10 PT)}

3.1. Univariate Analysis

3.1.1 General Characteristics of Respondents

\begin{tabular}{|c|c|c|c|c|c|}
\hline Indicator & Freq. & $(\%)$ & Mean & SD & $\rho$-value \\
\hline \multicolumn{6}{|l|}{ Age } \\
\hline Young Adult (20-40 y.o) & 1 & 9.1 & \multirow{3}{*}{59.18} & \multirow{3}{*}{11.932} & \multirow{3}{*}{0.154} \\
\hline Intermediate Adult (40-65 y.o) & 7 & 63.6 & & & \\
\hline Elderly (>65 y.o) & 3 & 27.3 & & & \\
\hline \multicolumn{6}{|l|}{ Gender } \\
\hline Female & 8 & 72.7 & \multirow{2}{*}{1.27} & \multirow{2}{*}{0.467} & \multirow{2}{*}{0.331} \\
\hline Male & 3 & 27.3 & & & \\
\hline \multicolumn{6}{|l|}{ Education } \\
\hline Elementary School & 4 & 36.4 & \multirow{3}{*}{3.18} & \multirow{3}{*}{0.982} & \multirow{3}{*}{0.893} \\
\hline Junior High School & 1 & 9.1 & & & \\
\hline Senior High School & 6 & 54.5 & & & \\
\hline \multicolumn{6}{|l|}{ Ocupation } \\
\hline Working & 5 & 45.5 & \multirow{2}{*}{1.55} & \multirow{2}{*}{0.522} & \multirow{2}{*}{1.000} \\
\hline Not Working & 6 & 54.5 & & & \\
\hline \multicolumn{6}{|l|}{ Religion } \\
\hline Islam & 10 & 90.9 & \multirow{2}{*}{1.36} & \multirow{2}{*}{1.206} & \multirow{2}{*}{0.163} \\
\hline Catholic & 1 & 9.1 & & & \\
\hline \multicolumn{6}{|l|}{ Income level } \\
\hline Without Income & 3 & 27.3 & \multirow{4}{*}{2.55} & \multirow{4}{*}{1.128} & \multirow{4}{*}{0.202} \\
\hline$\leq 500,000$ & 1 & 9.1 & & & \\
\hline $500,000-1,000,000 /$ Month & 5 & 45.5 & & & \\
\hline$\geq 1,000,000 /$ Month & 2 & 18.1 & & & \\
\hline
\end{tabular}

Based on the stages of age development, most of respondents in this study were at the stage of development of intermediate adult (40-65 years old) as many as 7 respondents or $63.6 \%$. For gender showed that as many as $72.7 \%$ or 8 respondents were female, while $27.3 \%$ or 3 respondents were male. Education level based on the results of the analysis, most of the education level of the respondents was Senior High School, as many as 54.5\% or 6 respondents and the occupation based on the results of the analysis, most of respondents were not working, as many as $54.5 \%$ or 6 respondents. Distribution of respondents based on the Religion from the 11 respondents, 10 respondents $(90.0 \%)$ were Muslim and 1 respondent was Catholic. Furthermore for income level from 11 respondents, 3 respondents $(27.3 \%)$ didn't have income and 5 respondents $(45.5 \%)$ had an income of 500,000-1,000,000/Month

3.1.2 A Review of Hypertension Risk Factors

Table 8 A Review of Hypertension Risk Factors

\begin{tabular}{ccc} 
Indicator & Frequency & $\begin{array}{c}\text { Percent } \\
(\boldsymbol{\%})\end{array}$ \\
\hline $\begin{array}{c}\text { Family History of Hypertension } \\
\text { Yes }\end{array}$ No & 7 & 63.6 \\
Con
\end{tabular}

Consumption of Salty Food 


\begin{tabular}{ccc} 
Yes & 10 & 90.9 \\
No & 1 & 9.1 \\
Fatty Food Consumption Habits & 9 & 81.8 \\
Yes & 2 & 18.2 \\
No & & \\
Smoking Habits & 3 & 27.3 \\
Yes & 8 & 72.7 \\
No & & 36.4 \\
Exercise Habits & 7 & 63.6 \\
No & & \\
\hline
\end{tabular}

The results of the analysis showed that as many as $63.6 \%$ or 7 respondents had a family history of suffering from hypertension, while respondents who did not have a family history of suffering from hypertension were $36.4 \%$ or 4 respondents. Majority of respondents have the habit of consuming salty foods as many as $90.9 \%$ or 10 respondents. The results of other analysis showed that the most of respondents said they liked to consume fatty foods, which were 9 respondents $(81.8 \%)$. Other analysis also showed that the most of the respondents were non-smokers as many as $(72.7 \%)$ or 8 . This was consistent with the previous analysis that the most of respondents of this study were female. This study also showed that as many as $63.6 \%$ or 7 respondents did not have exercise habits.

3.1.3 A Review of Stress

Table 9 A Review of Stress

\begin{tabular}{cccc}
\hline & Indicator & Frequency & Percent (\%) \\
\hline Stress & & 7 & \\
Yes & 4 & 63.6 \\
No & $\mathbf{1 1}$ & $\mathbf{1 0 0 . 0}$ \\
\hline Total & & 46.4 \\
\hline
\end{tabular}

The results of the analysis showed that the majority of respondents experienced stress in the past 1 month as many as $63.6 \%$ or 7 respondents, while respondents who did not experience stress in the past 1 month were $36.4 \%$ or 4 respondents.

3.1.4 BP Analysis Results

Table 10 Systolic Blood Pressure Analysis Results

\begin{tabular}{ccc}
\hline Pre & Post & Difference \\
\hline $179 \mathrm{mmHg}$ & $125 \mathrm{mmHg}$ & $54 \mathrm{mmHg}$ \\
$177 \mathrm{mmHg}$ & $140 \mathrm{mmHg}$ & $37 \mathrm{mmHg}$ \\
$140 \mathrm{mmHg}$ & $122 \mathrm{mmHg}$ & $18 \mathrm{mmHg}$ \\
$193 \mathrm{mmHg}$ & $165 \mathrm{mmHg}$ & $28 \mathrm{mmHg}$ \\
$149 \mathrm{mmHg}$ & $118 \mathrm{mmHg}$ & $31 \mathrm{mmHg}$ \\
$140 \mathrm{mmHg}$ & $110 \mathrm{mmHg}$ & $30 \mathrm{mmHg}$ \\
$143 \mathrm{mmHg}$ & $122 \mathrm{mmHg}$ & $21 \mathrm{mmHg}$ \\
$163 \mathrm{mmHg}$ & $140 \mathrm{mmHg}$ & $23 \mathrm{mmHg}$ \\
$167 \mathrm{mmHg}$ & $140 \mathrm{mmHg}$ & $27 \mathrm{mmHg}$ \\
$167 \mathrm{mmHg}$ & $140 \mathrm{mmHg}$ & $27 \mathrm{mmHg}$ \\
$173 \mathrm{mmHg}$ & $144 \mathrm{mmHg}$ & $29 \mathrm{mmHg}$ \\
\hline
\end{tabular}

Table 11 Diastolic Blood Pressure Analysis Results

\begin{tabular}{ccc}
\hline Pre & Post & Difference \\
\hline $80 \mathrm{mmHg}$ & $76 \mathrm{mmHg}$ & $4 \mathrm{mmHg}$ \\
$85 \mathrm{mmHg}$ & $80 \mathrm{mmHg}$ & $5 \mathrm{mmHg}$ \\
$95 \mathrm{mmHg}$ & $80 \mathrm{mmHg}$ & $15 \mathrm{mmHg}$ \\
$97 \mathrm{mmHg}$ & $75 \mathrm{mmHg}$ & $22 \mathrm{mmHg}$ \\
$67 \mathrm{mmHg}$ & $63 \mathrm{mmHg}$ & $4 \mathrm{mmHg}$ \\
$80 \mathrm{mmHg}$ & $70 \mathrm{mmHg}$ & $10 \mathrm{mmHg}$ \\
$85 \mathrm{mmHg}$ & $80 \mathrm{mmHg}$ & $5 \mathrm{mmHg}$ \\
$86 \mathrm{mmHg}$ & $89 \mathrm{mmHg}$ & $-3 \mathrm{mmHg}$ \\
$101 \mathrm{mmHg}$ & $89 \mathrm{mmHg}$ & $12 \mathrm{mmHg}$
\end{tabular}




$$
88 \mathrm{mmHg}
$$

$103 \mathrm{mmHg}$
$89 \mathrm{mmHg}$

$90 \mathrm{mmHg}$
$-1 \mathrm{mmHg}$ $13 \mathrm{mmHg}$

3.1.5 Changes in Average Blood Pressure

Table 12 Change in Average Systolic Blood Pressure

\begin{tabular}{lccccc}
\hline \multicolumn{1}{c}{ Indicator } & N & Min. & Max. & Mean & SD \\
\hline Pre-SDB & 11 & 140 & 193 & 162.82 & 17.713 \\
Post-SDB & 11 & 110 & 165 & 133.27 & 15.493 \\
\hline
\end{tabular}

The analysis showed that the average systolic BP on the first day before getting SDB exercise was $162.82 \mathrm{mmHg}$ with a standard deviation of 17.713 , while the average SBP on the 14th day after getting SDB exercise was $133.27 \mathrm{mmHg}$ with a standard with standard deviation of 15,493 . This showed that there was a decrease in SBP on the first day before giving SDB exercise and on the 14th day after giving SDB exercise.

Table 13 Change in Average Diastolic Blood Pressure

\begin{tabular}{lccccc}
\hline \multicolumn{1}{c}{ Indicator } & N & Min. & Max. & Mean & SD \\
\hline Pre-SDB & 11 & 67 & 103 & 87.91 & 10.559 \\
Post-SDB & 11 & 63 & 90 & 80.09 & 8.792 \\
\hline
\end{tabular}

The analysis showed that the average DBP on the first day before getting SDB exercise was $87.91 \mathrm{mmHg}$ with a standard deviation of 10.559 , while the average DBP on the 14th day after getting SDB exercise was $80.09 \mathrm{mmHg}$ with a standard deviation of 8.792 . This showed that there was a decrease in DBP on the first day before giving SDB exercise and on the 14th day after giving SDB exercise.

\subsection{Normality test}

Table 14 Normality Test of Systolic and Diastolic Blood Pressure

\begin{tabular}{lcccccc} 
& \multicolumn{2}{c}{ Kolmogorov-Smirnov } & \multicolumn{3}{c}{ Shapiro-Wilk } \\
SBP & Statistic & Df & $\rho$ value & Statistic & Df & $\rho$ value \\
\hline PRE SDB & 0.146 & 11 & 0.200 & 0.930 & 11 & 0.409 \\
POST SDB & 0.213 & 11 & 0.173 & 0.925 & 11 & 0.361
\end{tabular}

\begin{tabular}{lcccccc}
\hline & \multicolumn{2}{c}{ Kolmogorov-Smirnov $^{\text {a }}$} & \multicolumn{3}{c}{ Shapiro-Wilk } \\
DBP & Statistic & Df & $\rho$ value & Statistic & Df & $\rho$ value \\
\hline PRE SDB & 0.136 & 11 & $0.200^{*}$ & 0.954 & 11 & 0.690 \\
POST SDB & 0.208 & 11 & 0.199 & 0.905 & 11 & 0.212 \\
\hline
\end{tabular}

Shapiro Wilk's normality test results showed that the significance of $\rho$ value for SBP was 0.409 for Pre Intervention and 0.361 for post intervention, while the significance of $\rho$ value for DBP was 0.690 for Pre Intervention and 0.212 for post intervention. This showed that the significance of $\rho$ value for SBP and DBP was $>0.05$, so it could be concluded that the variable is normally distributed.

3.3 Bivariate Analysis

Table 15 Paired T-Test Analysis

\section{Paired Samples Test}

Mean $\quad \begin{gathered}95 \% \text { Confidence Interval of } \\ \text { the Difference }\end{gathered}$ Df $\rho$ value

\begin{tabular}{|c|c|c|c|c|c|c|}
\hline & & & Lower & Upper & & \\
\hline Systol Pre-Post & 29.545 & 9.595 & 23.099 & 35.992 & 10 & .000 \\
\hline Diastol Pre-Post & 7.818 & 7.360 & 2.874 & 12.762 & 10 & .006 \\
\hline
\end{tabular}

Based on the results of further analysis using paired t-test with SPSS 25 for windows, it could be seen the effect of SDB exercise on patients' BP with hypertension in working area of Kertosari Health Center with $\rho$ value of 0.000 . Based on these considerations, it could be concluded that the $\rho$ value SBP is $<0.05$. It means there was a significant Effect of SDB Exercise on Patients' Blood Pressure with Hypertension

\section{CONCLUSION (10 PT)}

The average respondent's SBP before SDB was $162.82 \mathrm{mmHg}$ and the average DBP before SDB was 87.91 $\mathrm{mmHg}$. In this study, most of the respondents' SBP showed the condition of second degree hypertension, but for the DBP most respondents included in first degree hypertension, namely $80-89 \mathrm{mmHg}$. The average SBP of the 
respondents after SDB was $133.27 \mathrm{mmHg}$ and the average DBP after SDB was $80.09 \mathrm{mmHg}$. Based on this classification, the respondent's BP after SDB intervention was in the first degree hypertension. The results of the study used the Paired T-Test Statistical Test to get $\rho$ value of 0,000 or $<0.05$, then $0,000<0.05$ Ho was rejected and $\mathrm{Ha}$ was accepted, It means there was a significant Effect of Slow Deep Breathing Exercise on Patients' Blood Pressure with Hypertension in the Working Area of Kertosari Health Center Banyuwangi 2020.

\section{ACKNOWLEDGEMENTS}

We would like to thanks all the persons who involved in this study for the collaboration, and our colleagues for their help in the process of the study. The last none of the authors have any conflict of interest.

\section{REFERENCES}

[1] V. J. Dzau and C. A. Balatbat, "Future of Hypertension The Need for Transformation," pp. 450-457, 2019, doi: 10.1161/HYPERTENSIONAHA.119.13437.

[2] L. A. E. Mohamed, N. F. Hanafy, and A. G. A. El-Naby, "Effect of slow deep breathing exercise on blood pressure and heart rate among newly diagnosed patients with essential hypertension," vol. 5, no. 4, pp. 36-45, 2016.

[3] I. Kurniawan and Helvetia, "Hubungan Olahraga , Stress dan Pola Makan dengan Tingkat Hipertensi di Posyandu Lansia di Kelurahan Sudirejo I Kecamatan Medan Kota," vol. 1, no. 1, pp. 10-17, 2019.

[4] B. Williams et al., "2018 ESC / ESH Guidelines for the management of arterial hypertension TheT ask Force for the management of arterial hypertension of the European Society of Cardiology and the European Society of Hypertension," no. August, pp. 1953-2041, 2018, doi: 10.1093/eurheartj/ehy339.

[5] W. Afiah, S. Yusran, and L. O. M. Sety, "Faktor Risiko Antara Aktivitas Fisik, Obesitas Dan Stres Dengan Kejadian Penyakit Hipertensi Pada Umur 45-55 Tahun Di Wilayah Kerja Puskesmas Soropia Kabupaten Konawe Tahun 2018," vol. 3, no. 2, pp. 1-10, 2018.

[6] WHO, "A Global Brief on Hypertension: Silent Killer, Global Public Health Crises," 2014.

[7] WHO, "A Global Brief on Hypertension: Silent Killer, Global Public Health Crises," 2015.

[8] WHO, "A Global Brief on Hypertension: Silent Killer, Global Public Health Crises," 2016.

[9] AHA, Cardiovascular Disease: A Costly Burden for America Projections Through 2035. Washington DC: The American Heart Association Office of Federal Advocacy, 2018.

[10]WHO, "Hypertension: Putting The Preasure On The Silent Killer," 2016. https://www.ifpma.org/\%0Awpcontent/uploads/2016/05/2016-\%0AHypertension-Putting-thepressure-on-thesilent-killer.pdf,\%0A.

[11] Ministry of Health, Window Buletin. Health Data and Information on Non-Communicable Disease. Jakarta, 2016.

[12] R. Kemenkes, Profil Kesehatan Indonesia 2018. Jakarta: Kementerian Kesehatan RI, 2018.

[13] A. R. Tarigan, Z. Lubis, and Syarifah, "Pengaruh Pengetahuan, Sikap Dan Dukungan Keluarga Terhadap Diet Hipertensi Di Desa Hulu Kecamatan Pancur Batu Tahun 2016," vol. 11, no. 1, pp. 9-17, 2018.

[14] R. Kementerian Kesehatan, "Hasil utama riskesdas 2018 provinsi jawa timur," pp. 1-82, 2018.

[15] B. Dinas Kesehatan, "Profil Kesehatan Kabupaten Banyuwangi Tahun 2018," Banyuwangi, 2018.

[16] WHO, "Hypertension Fact sheet," in Department of Sustainable Development and Healthy Environments, Regional Office for South East Asia, 2011, pp. 1-2.

[17] N. P. E. D. Yanti, I. A. L. Mahardika, and N. K. G. Prapti, "Pengaruh Slow Deep Breathing Terhadap Tekanan Darah Pada Penderita Hipertensi Di Wilayah Kerja Puskesmas I Denpasar Timur," J. Keperawatan dan Pemikir. Ilm., vol. 2, no. 4, pp. 1-10, 2016.

[18] Parikh, "Association between Liver Disease and Intracranial Hemorrhage," J. Stroke Cerebrovasc. Dis., vol. 25, no. 3, pp. 543-548, 2017, [Online]. Available: https://www.alodokter.com/yang-terjadi-jika-pembuluh-darahpecah-di-otak.

[19] K. T. Sebastianus, K. Tri Wulandari, and A. Khoiriyati, "Efektifitas Kombinasi Terapi Musik Dan Slow Deep Breathing Terhadap Penurunan Tekanan Darah Pada Pasien Hipertensi," Muhammadiyah J. Nurs., pp. 155-165, 2015, [Online]. Available: file:///C:/Users/User/Downloads/2075-5663-1-SM.pdf.

[20] G. S. Pongsibidang, "Risk Factor Hypertension, Diabetes And Consuming Herbal Medicine Of Chronic Kidney Disease In Dr. Wahidin Sudirohusodo Hospitals Makassar 2015," J. Wiyata, vol. 3, no. 2, pp. 1-6, 2016, doi: PISSN 2355 - 6498 |E-ISSN 2442-6555.

[21]N. Nipa, "Pengaruh Latihan Relaksasi Napas Dalam Terhadap Perubahan Skor Kecemasan Pasien Penyakit Ginjal Kronik Yang Menjalani Hemodialisis Di Rumah Sakit Pendidikan Universitas Hasanuddin," Hasanuddin University, 2017.

[22] R. Trybahari, Busjra, and R. Azzam, "Perbandingan Slow Deep Breathing Dengan Kombinasi Back Massage Dan Slow Deep Breathing Terhadap Tekanan Darah,” J. Telenursing, vol. 1, no. 1, pp. 106-118, 2019.

[23] P. A. L. Berek, E. Nurachmah, and D. Gayatri, "Effectiveness Of Slow Deep Breathing On Decreasing Blood 
Pressure In Primary Hypertension: A Randomized Controlled Trial Of Patients In Atambua , East Nusa Tenggara," Int. J. Sci. Technol., vol. 1, no. 2, pp. 1-14, 2015, [Online]. Available: http://grdspublishing.org/.

[24] AHA, 2019 ACC / AHA Guideline on the Primary Prevention of Cardiovascular Disease 2019 ACC / AHA Guideline on the Primary Prevention of Cardiovascular Disease. USA: American College of Cardiology/American Heart Association, 2019.

[25] A. Potter and A. Perry, Buku Ajar Fundamental Keperawatan: Konsep, Proses, dan Praktik, 4th ed. Jakarta: EGC, 2017.

[26]H. Azhari, "Faktor-Faktor yang Berhubungan dengan Kejadian Hipertensi di Puskesmas Makrayu Kecamatan Ilir Barat II Palembang," J. Ilm. Kesehat., vol. 2, no. 1, pp. 23-30, 2017.

[27] et al Pinheiro, "Spontaneous Respiratory Modulation Improves Cardiovascular Control in Essential Hypertension," 2014. http:www.scielo.br/pdfabc/v88 n6/en_v88n6a05.pdf.

[28] C. N. Joseph et al., "Slow breathing improves arterial baroreflex sensitivity and decreases blood pressure in essential hypertension," AHA Journals, vol. 4, no. 6, pp. 714-718, 2016, [Online]. Available: http://hyper.ahajournals.org/.

[29] E. Grossman, A. Grossman, M. H. Schein, R. Zimlichman, and B. Gavish, "Breathing-Control Lower Blood Pressure," 2014. http:www.nature.com/jhh/journal/v15/n4/pdf/1001147a.pdf.

[30] G. K. Pal, Velkumary, and Madanmohan, "Effect of Short-Term Practice of Breathing Exercise on Autonomic Function in Human Volunteers," 2015. http:icmr. nic.in/ijmr/2004/0807.pdf. 
